\title{
Semi-Strong Form of Efficiency of Nigerian Stock Market: An Empirical Test in the Context of Input and Output Index
}

\author{
Ajayi John Ayodele ${ }^{1}$, Segun Anthony Oshadare ${ }^{1} \&$ Olufunmilayo Adekemi Ajala $^{2}$ \\ ${ }^{1}$ Department of Banking and Finance, Federal University of Agriculture, Abeokuta, Ogun State, Nigeria \\ ${ }^{2}$ Department of Banking and Finance, The Polytechnic, Ibadan, Oyo State, Nigeria \\ Correspendence: Ajayi John Ayodele (PhD), Department of Banking and Finance, Federal University of Agriculture, \\ Abeokuta, Ogun State, Nigeria.
}

Received: August 25, 2017

Accepted: December 8, 2017

Online Published: December 13, 2017

doi:10.5430/ijfr.v9n1p115

URL: https://doi.org/10.5430/ijfr.v9n1p115

\begin{abstract}
This paper examines the semi-strong form of efficiency of the Nigerian stock market. Such examination is made in the context of whether information impounded in previous stock prices reflect current prices through the input and output index. Data for the study were from secondary sources and it spans from 2005-2013. The population for this study encompasses all the companies that traded in the period of January 1, 2005 to December 31, 2013. All these companies are ranked according to their capitalization and a random sampling technique was employed to select the companies that have the capitalization values above the average value. The study made use of modified transfer function model to estimate the market index which is represented by the outputindex and the computed selected securities represented by the input index which is tantamount to published information. Findings from the paper show that publicly published information captured by the input index commands significant effect on the stock market represented by the output index hence making the Nigerian stock market to be semi-strong inefficient.
\end{abstract}

Keywords: modified transfer function, impounded information, semi-strong, stock market, input-output

\section{Introduction}

In order to accelerate economic development and bring about capital formation which is an essential ingredient of growth in any economy, the capital market needs to be developed. However, in Nigeria, the stock market is still underdeveloped and emerging due to myriads of problems such as low level of automation, lack of adequate and timely information among others (Olowe, 2011).

The Nigerian capital market is small even when compared with other emerging stock markets (Samuel and Yacout (1981), Ogwumike (1982), Umoh, (1984), Inanga and Emenuga (1996), Olowe (1996, 2011), Okpara, (2011), Oteh (2014) among others.

Apart from the above identified problems, the Nigerian stock market still has a long way to go when compared with those in some developed countries. For example, up till date, it has thirteen functional floors in different parts of the country apart from the head office in Lagos, other branches of the Exchange include; Kaduna, Kano, Ibadan, Port Harcourt, Onitsha, Abuja, Yola, Benin, Uyo, Abeokuta, Owerri, Bauchi and Ilorin with over 200 listed equities. This looks shallow when compared with the Indian Stock Exchange with about 4,344 companies or the London Stock Exchange with about 5,085 listed companies (Oteh, 2013).

Adelegan and Ariyo (2008) noted that the shallowness of the market has led to many imperfections that are reflected in microstructure elements such as high transaction costs. In the face of such shallowness and imperfections, how can one assert assuredly that the Nigerian stock market is efficient?

Kukah, Amoo and Raji (2007) contended that the Nigerian stock market is thin and asserted that "one of the reasons for inefficiency may be the thin trading that characterizes Nigerian markets since stock trading in the Nigerian Stock Exchange is non synchronous causing trading volume to be low". The problem of thinness of the market has incited observers to conclude that the market is not perfect and hence inefficient. Such conclusions incite this empirical investigation. 


\subsection{Objective of the Study}

The main objective of this study is to examine whether information impounded in previous stock prices reflect current prices

\subsection{Research Hypothesis}

To accomplish the above objective, the hypothesis below which is in null form is formulated and tested for the study.

$\mathrm{H}_{0}$ : That the information impounded in previous stock prices does not reflect the current prices.

\section{Literature Review}

Fama (1970) is the proponent of efficient capital markets. He opined that there are three main forms of market efficiency, namely, the weak-form, semi-strong form and strong form.

Under a weak -form efficiency, asset prices incorporate all information from the historical record. In other words, prices in a weak-form efficient market incorporate all information about price trends or repeating patterns that occurred in the past. This proposition implies that trading strategies based on analysis of historical pricing trends or relationship cannot be used to outperform the market. Prices in a weak -form efficiency will be unpredictable and will change only in response to the arrival of new information. In order words, this means that prices follow a random walk.

Fama (1970), Kendall (1953), Osborne (1959), Yacout (1981), Ayadi (1983), Olowe (1996), Adelegan (2003), Okpara (2011) among others showed that the stock market is efficient in the weak form. These studies were arrived at in different countries.

The semi-strong form efficiency asserts that asset prices incorporate all publicly available information. The key point about this form of efficiency is that it requires only that prices reflect information that can be gleaned from public sources (e.g. newspapers, press releases and computer databases). There is both "stock" and "flow" aspect to the information- processing capabilities of semi strong-form efficient markets: first, the level of asset prices should correctly reflect all pertinent historical, current, and predictable future information that investors can obtain from public sources. Second, asset prices should change fully and instantaneously to the arrival of new information.

Ball and Brown (1968), Fama, Fisher and Roll (1969), Aharony and Swary (1980), Gupta (2003), Raja et. al (2009), Adelegan (2009) Rapulchukwu (2010), Chakraborty (2011), Ogundina, Ajala and Soyebo (2014), Ogege, Ogbulu and Isu (2015), arrived at different conclusions in their studies.

The strong-form efficiency is the third level of efficiency where asset prices reflect all information, public and private. This extreme form of market efficiency implies that important-specific information will be fully incorporated in asset prices with the very first trade after the information is generated.

A cursory look at the literature above on semi- strong efficiency theory which is the focus of this study shows that few studies have been carried out on this form of efficiency in Nigeria. However, there has not been consensus on the few studies. This forms the gap and motivation which this study hinges upon.

\section{Model for the Study}

The transfer function (TF) model by Joseph (1986) is adopted for this study with some modifications. The general form of this model is stated below:

$$
M k t_{\text {ind(t) }}=f\left(\mathrm{CS}_{\text {ind1t }}, \mathrm{CS}_{\mathrm{id} 2 \mathrm{t}}, \ldots \ldots \ldots . . . \mathrm{CS}_{\mathrm{nt}}\right)+\mu_{\mathrm{it}} \ldots
$$

Where: $\mathrm{Mkt}_{\text {ind }}$ is the market index representing the output series

$\mathrm{CS}_{\mathrm{nt}}$ is the computed selected securities index representing $\mathrm{n}^{\text {th }}$ the publicly information i.e. the input series or causor series. $u_{t}$ is the noise term which requires an appropriating fitting of the autoregressive integrated moving average (ARIMA) model so as to transform it to become white noise. That is it becomes identically and independently (IID) compliant.

In financial time series, the commonest TF models are the 0 and first order TF model while the higher order TF models are really seldom and rare to encounter. We, therefore develop the 0 and first order TF model for this study. Thus:

$$
\mathrm{Mkt}_{\text {ind(t) }}=\beta_{0} \mathrm{CS}_{\text {indt-p}}+\mu_{2 \mathrm{t}}
$$

Where: $\mathrm{p}$ represents the number of period(s) the input series is leading the output series

${ }_{0}$ denotes the 0 -order TF coefficient

Equation 3.2 is called the 0 -order TF model. However, the first order TF model can be expressed as: 


$$
\mathrm{Mkt}_{\text {ind(t) }}=\beta_{0}\left(1-\partial_{1} \mathrm{~L}^{-1} \mathrm{CS}_{\text {ind } t-\mathrm{p}}+\mu_{3 \mathrm{t}}\right.
$$

Equation 3.3 is simplified further to arrive at:

$$
\underset{\left(1-\partial_{1} L\right)}{M k t_{\text {ind }(t)}=} \beta_{0} \quad \mathrm{CS}_{\text {ind } t-p} \mu_{4} \mathrm{t}
$$

Where: $\beta_{0}$ and $\partial_{1}$ are the coefficients of the first order TF model specification

$\mathrm{L}$ is the backward shift operator that enables us to move backward in given series whichever the case demands it. For example, a time series such as $\mathrm{LX}_{\mathrm{t}}$ can move back to become $\mathrm{X}_{\mathrm{t}-1}$ as we have said earlier, the expression $\partial_{1} \mathrm{~L}$ does not apply multiplication; but it simply means that $\mathrm{L}$ operates on the given time series (say $\mathrm{X}_{\mathrm{t}}$ ) to shift it backward one point at a time.

Thus, $\mathrm{L}^{\mathrm{n}} \mathrm{X}_{\mathrm{t}}=\mathrm{X}_{\mathrm{t}-\mathrm{n}}, \mathrm{L}^{\mathrm{n}} \mathrm{L}^{2} \mathrm{X}_{\mathrm{t}}=\mathrm{X}_{\mathrm{t}-\mathrm{n}-\mathrm{z}}$. It means that $\mathrm{L}$ obeys all the laws of exponents and it can therefore take the form of positive integer like $1,2,3 \ldots$ it should be clear $t$ at $1 /\left(1-\partial_{1} L\right)$ is the convergence of a infinite series. That is $\left(1+\partial_{1} \mathrm{~L}\right.$ $\left.+\partial_{1}{ }^{2} \mathrm{~L}^{2}+\partial_{1}{ }^{3} \mathrm{~L}^{3}+\partial_{1}{ }^{4} \mathrm{~L}^{4}+\ldots \ldots \ldots.\right)$

Therefore, equation 3.4 becomes:

$$
\mathrm{Mkt}_{\text {ind(t) }}=\beta\left(1+\partial_{1} \mathrm{~L}+\partial_{1}{ }^{2} \mathrm{~L}^{2}+\partial_{1}^{3} \mathrm{~L}^{3}+\ldots \ldots\right) \mathrm{CS}_{\text {indt }}+\mu_{5 \mathrm{t}}
$$

Since the $\mathrm{L}$ operator must obey all the laws of exponents that are routinely used in polynomial algebra, equation 3.5 can be modified as:

$$
\mathrm{Mkt}_{\text {ind }(\mathrm{t})}=\beta_{0} \mathrm{CS}_{\text {indt }}+\partial_{1 \beta} \mathrm{S}_{\text {indt-1 }}+\partial_{1{ }_{\beta 0}}^{2} \mathrm{CS}_{\text {indt-2 }}+\mathrm{U}_{6}
$$

Equation 3.6 shows a causal relationship between current market index and previous values of the computed securities index. Thus, the notion established here is that lag values of publicly available input series can be used to forecast or explain the current value of the output series if all the parameters are significant.

The conditions relating to this model are:

That coefficient $\beta_{0}$ is not statistically different from zero.

That coefficients $\left(\partial_{1 \mathrm{~B}} 0\right)^{\mathrm{i}}$ are statistically different from zero

On the apriori: The semi-strong form of the efficient market hypothesis (EMH) is rejected when the TF coefficients are significant or different from zero at a given level of confidence.

Looking critically in the literature, our primary aim here is to identify at least one publicly available input series with $\beta_{0}$ coefficient that leads the output series for at least 1 day for 0 -order TF model or to identify at least one publicly available input series with significant parameter for the first order TF model that leads the output series, then, we can say that the semi-strong form of efficient market hypothesis is unambiguously rejected.

\subsection{Population of the Study}

The study examines the Nigerian stock market on the level of its efficiency based on semi-strong hypothesis over a period of 2005 to 2013. Therefore, all the companies that retain their quoting status within the range of January 1 , 2005 to December 31, 2013 with thin or bogus trading activity form the population of this study.

\section{Results and Discussion}

\subsection{Historical Movements of the Output and Input Series}

The movements of these series over the sampling period ranging from January $31^{\text {st }} 2005$ to December $31^{\text {st }} 2013$ are shown graphically in the figures below: 


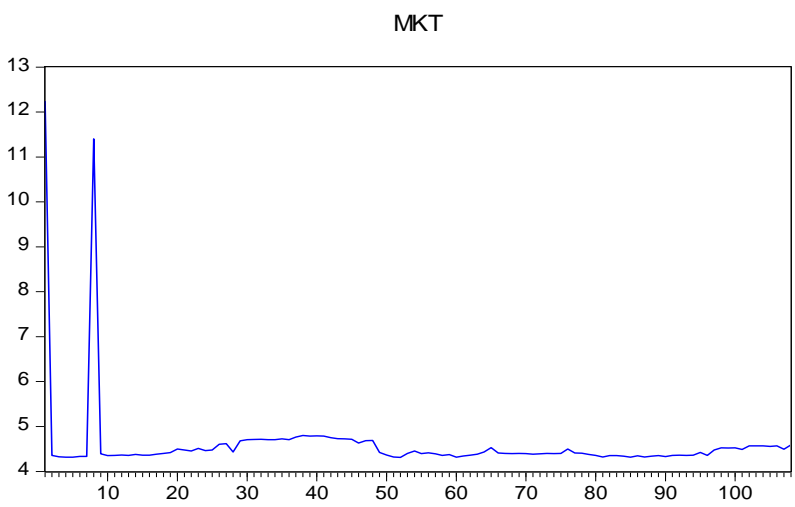

Figure 1. Movement of the stock market index

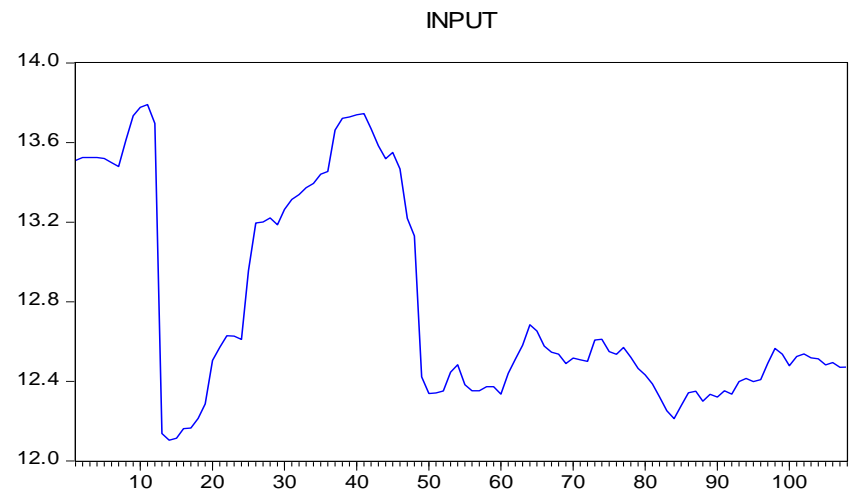

Figure 2. Movement of the input index

Figures 1 and 2 respectively demonstrate the movements of the Nigerian stock market and the publicly published information over a specified trend. The volatility of the stock market is characterized with outliers in the beginning of the study, probably in the first ten months. While the output series is riddled with outliers through the period of investigation. Outliers are markets features that are difficult to predict due to their instability or non-stationarity in nature.

Test of Hypothesis: That the information impounded in the previous stock prices does not reflect current prices.

The above hypothesis is tested in the relationship between the output and input index as shown in the table below:

Table 1. The relationship between the output and input index

Conditional Least Squares Estimation

\begin{tabular}{lllllll}
\hline \multicolumn{1}{c}{ Standard } \\
Parameter & Estimate & Error & t Value & Lag & Variable & Shift \\
\hline MU & -0.56926 & 1.72271 & -0.33 & 0 & output & 0 \\
\hline NUM1 & 0.61354 & 0.37439 & 1.64 & 0 & input & 0 \\
\hline NUM1,1 & 0.38297 & 0.55507 & 0.69 & 1 & input & 0 \\
\hline NUM1,2 & -0.03740 & 0.55504 & -0.07 & 2 & input & 0 \\
\hline NUM1,3 & 0.13230 & 0.37103 & -0.36 & 3 & input & 0
\end{tabular}

Source: Summarized by the Authors from SAS Window 9.1 
The estimated values of equation 3.5 are reported in Table 1. The lag values of the input index are expressed as explanatory variables of the output index. The observed t-statistics for the input index up to lag 3 are 1.64, 0.69, $-0.07 \&-0.36$ respectively while the critical t-statistics at 10 percent is about 1.29 . By comparison, the $t$-value of the input index at order (0) is larger than the critical $t$-value. This means that publicly published information captured by the input index commands significant effect on the stock market (represented by the output index), thereby negating the null hypothesis of the study that the information impounded in previous stock prices does not reflect current prices.

On the contrary, the semi-strong market hypothesis stipulates that published information does not influence stock market prices; so no investor can take advantage of published information to outperform the market or make gain at the expense of other participants.Thus, our findings here provide evidence in support of semi-strong form of inefficiency in the Nigerian stock market.

\section{Concluding Remarks}

This paper sets out to investigate the semi- strong form of market efficiency of the Nigerian stock market as to whether information impounded in previous stock prices reflect current prices using the input and output index. Data for the study covered the period 2005-2013. The study made use of modified transfer function model to estimate the market index which is the output index as well as the input index represented by the computed selected securities.

A transfer function model of order zero and the first order TF was also used. The model also builds a casual relationship between the current market index and the previous values of the computed securities index in establishing the notion that lag values of publicly available input series can be used to forecast or explain the current value of the output series if all the parameters are significant. An hypothesis was formulated and tested for the study.

Results from the study show that the t- value of the input index at order zero is larger than the critical t-value meaning that publicly published information captured by the input index commands significant effect on the Nigerian stock market thereby negating the null hypothesis that information impounded in previous prices does not reflect current prices thus making the Nigerian stock market to be semi-strong inefficient.

\section{References}

Adelegan, O.J. (2009). Price reactions to dividends announcements on the Nigerian stock exchange. African Economic Research ConsortiumResearch Paper, 188, July, 1-2.

Adelegan, O.J., \& Ariyo, A. (2008). Capital market imperfections and corporate investment behavior. A switching regression approach using panel data for Nigerian manufacturing firms. Journal of Money, Investment and Banking, 2, 16-38.

Aharony, J., \& Swary, I. (1989, March). Quarterly dividend and earningsannouncements and stockholders' returns: An empirical analysis. The Journal of Finance, 35(1), 1-12.

Ajayi, J.A., \& Ogbulu, O. M. (2017). Test of the semi-strong efficiency theory in the Nigerian stock market: An empirical analysis. Journal of Financeand Accounting, 5(4), 139-146.

Ajayi, J.A., et al. (2017). Empirical test of the martingale property in stock market: Evidence from Nigeria. Journal of Finance and Accounting, 5(4), 147-150. https://doi.org/10.11648/j.jfa.20170504.14

Arewa, A. (2014). Applicability of the single-factor and multi-indexedasset pricing models: Evidence from the Nigerian capital market. Unpublished PhD Dissertation, University of Port Harcourt.

Ayadi, F.O. (1984, March). The random walk hypothesis and the behaviour of share prices in Nigeria. Niigerian Journal of Economics and Social Studies, 26(1), 57-71.

Ball, R., \& Brown, P. (1968). An empirical evaluation of accountingincome number. Journal of Accounting Research, 6(2), 159-178. https://doi.org/10.2307/2490232

Emenuga, C. (1989). An econometric analysis of the relationship between money supply and stock prices in Nigeria. Unpublished M.Sc Thesis, Department of Economics, University of Ibadan.

Fama, E.F. (1991, December). Efficient capital markets: II. Journal of Finance, 46(5), 1575-1617.

Fama, E.F., Fisher, I. Jensen, M., \& Roll, R. (1969). The adjustment of Stockprices to new information. International Economic Review, 10, 1-21. https://doi.org/10.2307/2525569

Inanga, E.L. (1997). Institutional traditional and asset pricing characteristics of the Nigeria stock exchange. African EconomicResearch Consortium Research Paper, 60, March. 
Joseph, W.C. (1986). An alternative semi-strong form test of the efficient market hypothesis by a transfer function approach. Unpublished MBA Dissertation, Simon Fraser University, Canada.

Kaur, P. (2010). Valuation effect of stock split in India: Case of BSEsensex constituents. Finance India, XXIV(3), 813-831.

Kukah, et al. (2007). Analytical framework and empirical analysis of transaction costs and efficiency of the Nigerian capital market. CBN Research and Statistics Department.

Ogege, S., Ogbulu, O. M., \& Isu, H. O. (2015). Earnings and dividend announcements, semi- strong efficiency and the Nigerian stock market: An empirical investigation. Archives of Business Research, 3(4), 104-123, https://doi.org/10.14738/abr.34.1366

Ogundina, J. A. (2015). Empirical test of the semi-strong efficiency theory in the Nigerian stock market. Unpublished PhD Thesis, AbiaState University, Uturu.

Ogundina, J.A., Ajala, O.A., \& Soyebo, Y. A. (2014). The test of the semi-strong efficiencytheory in the Nigerian capital market: An empirical analysis in thecontext of dividend announcements. International Journal of Financial Economics, 3(1), 57-69.

Ogwumike, F.O. (1982). The effect of dividends and retained earningson share prices in Nigeria. Unpublished M.Sc Project, University of Ibadan, Nigeria.

Okpara, G.C. (2011). Analysis of the efficiency and prediction power of the Nigerian stock market (1984-2009). An Unpublished PhD Thesis. Department of Banking and Finance, Abia State University, Uturu.

Olowe, R.A. (1999). Weak from efficiency of the Nigerian stock market:Further evidence. African Development Review, 11(1), Black Well: African Development Bank.

Olowe, R.A. (2011). Financial Management. Lagos: ForthrightPublishers.

Oteh, A. (2014). E-payment will address the problem of unclaimed missing dividends. The Nigerian Punch, Friday, April 28.

Rapuluchukwu, E.U. (2010). The efficient market hypothesis: Realitiesfrom the Nigerian stock market. Global Journal of Finance and Management, 2(2), 321 -331.

Samuel, J.M., \& Yacout N. (1981). Stock exchange in developingcountries. Savings and Development, 5(4), 217-230.

Tomasz, P., \& Tomasz, S. (2012). Empirical test of the strong form efficiency of the Warsaw stock exchange: The analysis of WIG 20index shares. South- Eastern Europe Journal of Economics, 2, 155-172. 